\title{
Genetic Diversity of Parkia biglobosa from Different Agroecological Zones of Nigeria Using RAPD Markers
}

\section{Oluwafemi Amusa, ${ }^{1,2}$ Adenubi Adesoye, ${ }^{2}$ Adebayo Ogunkanmi, ${ }^{1}$ Ojobo Omoche, ${ }^{2}$ Olumayowa Olowe, ${ }^{2}$ Solomon Akinyosoye, ${ }^{3}$ and Taiwo Omodele ${ }^{3}$}

${ }^{1}$ Department of Cell Biology and Genetics, University of Lagos, Akoka, Nigeria
${ }^{2}$ Department of Botany, University of Ibadan, Ibadan, Nigeria
${ }^{3}$ Institute of Agricultural Research and Training, Moor Plantation, Ibadan, Nigeria

Correspondence should be addressed to Oluwafemi Amusa; femisworld@yahoo.com and Adenubi Adesoye; aadesoye@yahoo.com

Received 13 August 2014; Accepted 16 October 2014; Published 9 November 2014

Academic Editor: Alexandre Sebbenn

Copyright (C) 2014 Oluwafemi Amusa et al. This is an open access article distributed under the Creative Commons Attribution License, which permits unrestricted use, distribution, and reproduction in any medium, provided the original work is properly cited.

Parkia biglobosa (Jacq.) is an important leguminous tree crop in the African Savannahs useful to the natives where it is found, for domestic use. Previous diversity studies on this tree crop had been majorly on morphological and biochemical analysis. In order to capture the maximum diversity not obtained by previous research, the study aimed at evaluating the genetic diversity of accessions of this crop in the different agroecological zones in Nigeria using RAPD markers. A total of 81 scorable bands with an average of 8.1 bands per primer were amplified among the accessions studied. Intrazonal genetic diversity analysis showed a percentage polymorphism with a range of $11.11 \%$ to $65.43 \%$ among the agroecological zones studied. Although, gene diversity was highest within Humid forest agroecological zone, a low genetic distance and high genetic similarity between the agroecological zones were observed. Cluster analysis indicated six main groups of which four groups had single accessions while the two groups clustered the remaining accessions, indicating a narrowed genetic base from the 23 accessions studied.

\section{Introduction}

The African locust bean plant (Parkia biglobosa) is a perennial tree legume belonging to the subfamily Mimosoideae of the family Fabaceae. It is one of the thirty-four known species of the genus Parkia whose centre of origin is South America. Distributed in a belt between latitudes $5^{\circ} \mathrm{N}$ and $15^{\circ} \mathrm{N}$, and longitudes $16^{\circ} \mathrm{W}$ and $32^{\circ} \mathrm{W}$, from the Atlantic coast in Senegal to Southern Sudan and Northern Uganda in the African continent, it has its greatest belt (about $800 \mathrm{Km}$ ) in West Africa and narrows to the east $[1,2]$.

Aside from its ecological role in cycling of nutrients $[3,4]$, it is a valuable source of food especially the seeds which serves as a source of useful spices for cooking $[1,5,6]$. Kwon-Ndung et al. [7] reported that it is a very important tree crop in the Africa Savannas where the natives use it as medicine, glaze for ceramic pots, fodder, firewood, and charcoal production. Parkia tree is also used as timber for making pestles, mortars, bows, hoe handles, and seats [8,9] while the husks and pods are good food for livestock [10].

Previously, studies on diversity within this species focused on accessions from West African countries like Burkina Faso, Benin, and Uganda with only three accessions collected from the Southern Guinea Savanna in Nigeria [11-13]. These studies dealt majorly with phenotypic and anatomical diversity within species of the plant. P. biglobosa is however known to occur in diverse agroecological zones in Nigeria ranging from tropical rain forests to arid zones, from the lower Sudan Savanna to Derived Savanna and the Lowland forest. Adesoye et al. [14] reported variations in accessions of $P$. biglobosa collected across different agroecological zones (AEZ) of Nigeria based on seedling morphological characteristics evaluated.

Beyond the phenotypic and anatomical estimations of diversity, the heritable variations observed in plants (termed plant genetic diversity) can also be evaluated using agromorphological, biochemical, and molecular data. Molecular 
diversity however outweighs others since it is less affected by environmental factors. Maintaining genetic diversity within species is important for effective conservation of genetic resources, ensuring variation for crop improvement and adaptability to the ever-changing environmental challenges.

Owing to the limited information on the species diversity in Nigeria, this study sought to elucidate the genetic diversity among the Nigerian accessions of $P$. biglobosa from seven AEZ using rapid amplified polymorphic DNA (RAPD) markers. Although RAPD markers are criticized for their lack of reproducibility, yet they are thought to be good markers for elucidating overall genetic diversity especially where the diversity of such species has not been previously known. It has been used for genetic diversity assessment and for identifying germplasm in a number of plant species $[15,16]$. Subramanyam et al. [17] reported that RAPD provides information that can help define the distinctiveness of species and phylogenetic relationships at molecular level.

\section{Materials and Methods}

2.1. Plant Material. To carry out our genetic study, openpollinated seeds were collected from twenty-three (23) accessions of $P$. biglobosa collected from different states and locations within the seven (7) agroecological zones in Nigeria (Table 1, Figure 1).

Dry seeds of each accession per zone were tested for viability using the simple floating test. The seeds considered viable after the test were collected for planting. To break the seed dormancy, the selected seeds were immersed in concentrated hydrogen tetraoxosulphate (VI) acid for 15 minutes. The seeds were rinsed trice in distilled water and air dried at room temperature before planting in plastic bags.

2.2. DNA Extraction and RAPD Analysis. Sample DNA was extracted from $0.3 \mathrm{~g}$ young leaves using modified Dellaporta et al. [18] protocol. The extracted DNA was dissolved in low Tris EDTA buffer and stored at $-20^{\circ} \mathrm{C}$ until use. Ten decamer primers were used to evaluate genetic diversity among the accessions collected. PCR reaction was carried out in a $25 \mu \mathrm{L}$ volume reaction $\left(2.5 \mu \mathrm{L} 10 \mathrm{x}\right.$ buffer, $1.2 \mu \mathrm{L} \mathrm{MgCl}_{2}$, $2.0 \mu \mathrm{L}$ dNTPs, $1.0 \mu \mathrm{L}$ DMSO, $1.0 \mu \mathrm{L}$ primer, $0.2 \mu \mathrm{L}$ Taq, $1.0 \mu \mathrm{L}$ DNA template, and $16.1 \mu \mathrm{L} \mathrm{dH_{2 }} \mathrm{O}$ ). The mixture was overlaid with $20 \mu \mathrm{L}$ of sterile mineral oil.

DNA amplification reaction was carried out in a Perkin Elmer Centus Thermocycler. For each amplification process, a preheating denaturation of DNA at $94^{\circ} \mathrm{C}$ for $3 \mathrm{~min}$ was done, followed by 44 amplification cycles (each $94^{\circ} \mathrm{C}$ for $20 \mathrm{secs}, 35^{\circ} \mathrm{C}$ for $40 \mathrm{secs}$, and $72^{\circ} \mathrm{C}$ for $1 \mathrm{~min}$ ). A final extension of $7 \mathrm{~min}$ at $72^{\circ} \mathrm{C}$ was performed. The amplified fragments were then run on $1.5 \%$ agarose in $0.5 \mathrm{M} \mathrm{TBE}$ buffer at $100 \mathrm{~V}$ for 3 hours. Gels were stained with $0.5 \mu \mathrm{g} / \mathrm{mL}$ ethidium bromide and visualized under a high-performance UV light. The observed bands were scored 1 where present and 0 where absent. The data generated were analyzed using Numerical Taxonomic System of Statistics (NTSYS) and Popgene 1.31 software. Nei and Li [19] formula was used to estimate the genetic similarities, distances, and percentage
TABLE 1: P. biglobosa collections from different agroecological zones of Nigeria.

\begin{tabular}{lcc}
\hline State & Location & Accession number \\
\hline Abuja & Municipal & P3 \\
Bauchi & Katagum & P22 \\
Benue & Vandiekya & P5 \\
Benue & Akpagher, Gboko & P11 \\
Delta & Kaboro & P9 \\
Gombe & Kaltungo & P14 \\
Kaduna & Chikun & P23 \\
Kaduna & Zaira & P24 \\
Kano & Nasarawa & P15 \\
Katsina & Mani & P13 \\
Niger & Doko Village & P6 \\
Ogun & Abeokuta, Abeokuta North & P4 \\
Ogun & Ago Sasa, Ipokia & P36 \\
Ondo & Oba, Akoko & P2 \\
Ondo & Akungba, Akoko & P7 \\
Ondo & Enpare, Akoko & P8 \\
Oyo & NIHORT, Ibadan & P1 \\
Oyo & Saki, Saki East & P12 \\
Plateau & Isaya, Bassa & P10 \\
Plateau & Guanawuri, Riyom & P31 \\
Plateau & Soukwa & P32 \\
Yobe & Bade, Gashua & P16 \\
Yobe & Ubu & P28 \\
\hline
\end{tabular}

TABLE 2: List of RAPD primers used.

\begin{tabular}{llc}
\hline Primers & Sequence $^{\prime} \rightarrow 3^{\prime}$ & Polymorphic bands \\
\hline OPD-17 & -TTTCCCACGG- & 12 \\
OPAD-05 & -ACCGCATGGG- & 10 \\
OPAE-11 & -AAGACCGGGA- & 6 \\
OPAE-14 & -GAGAGGCTCC- & 6 \\
OPAC-11 & -CCTGGGTCAG- & 6 \\
OPAE-09 & -TGCCACGAGG- & 4 \\
OPB-01 & -GTTTCGCTCC- & 11 \\
OPB-02 & -TGATCCCTGG- & 7 \\
OPF-10 & -GGAAGCTTGG- & 10 \\
OPG-03 & -GAGCCCTCCA- & 9 \\
\hline
\end{tabular}

polymorphisms within and between the accessions. The total number of alleles observed and alleles effective in detecting polymorphism were also recorded. Dendrogram showing the relationship between the accessions was constructed from Jaccard's similarity coefficients using unweighted pair group method of arithmetic means (UPGMA).

\section{Results}

The bands generated ranged from 700 to 6000 base pairs (bp) with majority falling between 1000 and 4000 bp (Figure 2).

The polymorphic bands observed ranged from 6 to 12 (Table 2) with an average of 8.1 bands per primer. A total of 81 scorable bands were amplified among the 23 accessions of P. biglobosa studied. 


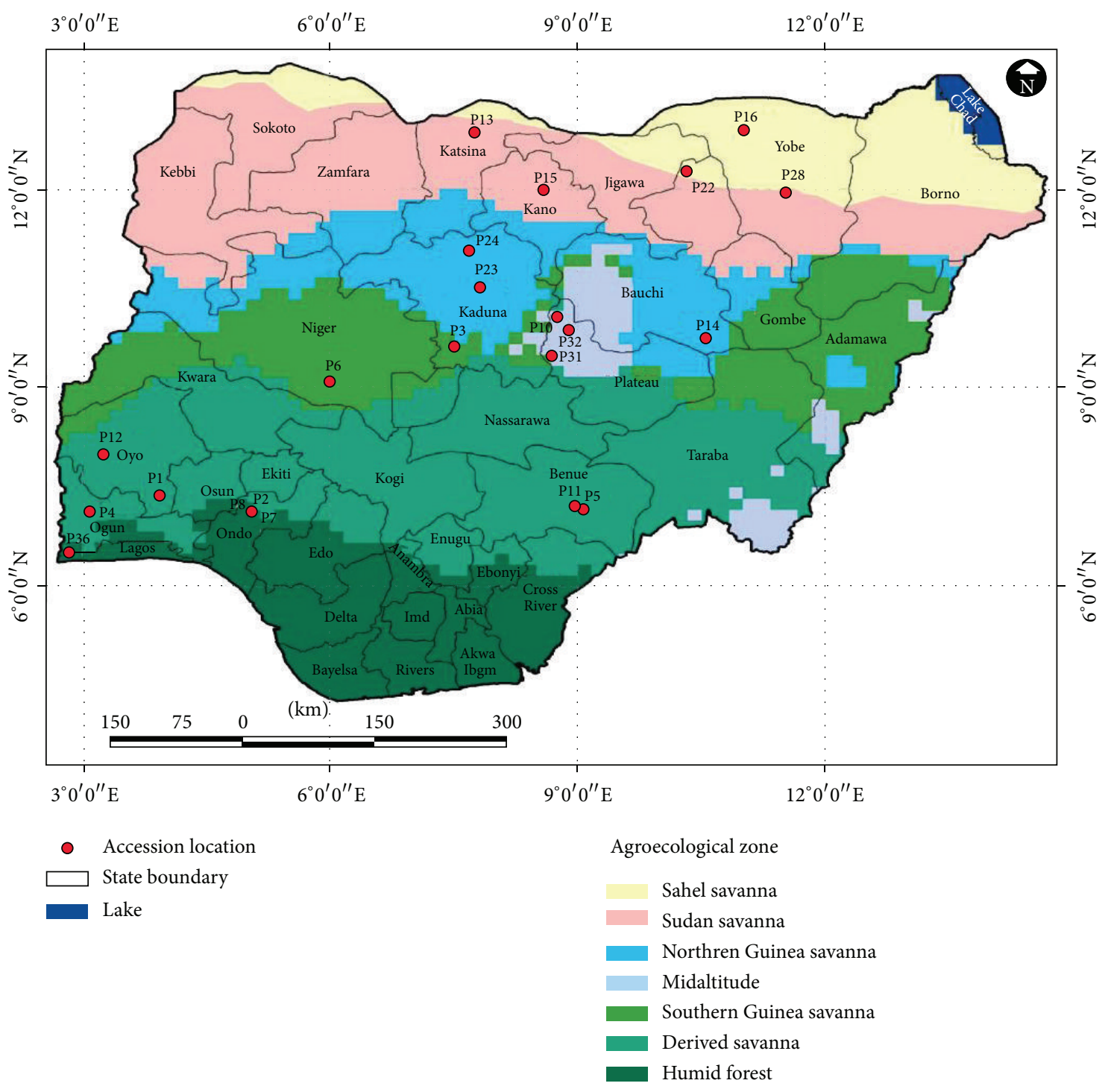

FIgURE 1: Geographical locations of Parkia accessions used for study analysis.

The percentage polymorphism ranged from 11.11 to $65.43 \%$ (Table 3), with the two agroecological zones (Derived Savanna and Humid forest) showing the highest number (53) of polymorphic loci and percentage polymorphism (65.43\%) while North Guinea Savanna had the least number of (9) polymorphic loci and percentage polymorphism $(11.11 \%)$.

Within the agroecological zones, two agroecological zones showed the highest number of observable alleles of 1.65 \pm 0.48 with $1.21 \pm 0.24$ and $1.25 \pm 0.24$ effective number of alleles for derived Savanna and for Humid forest, respectively (Table 3). However, North Guinea Savanna showed the least observed number of alleles $(1.11 \pm 0.32)$ with $1.09 \pm 0.26$ effective number of alleles. Analysis showed that the greatest gene diversity was found in Humid forest $(0.18 \pm 0.14)$ and least diversity in Sudan Savanna $(0.05 \pm 0.14)$ and North Guinea Savanna $(0.05 \pm 0.13)$.
Interzonal genetic diversity between the various AEZs indicated a high genetic similarity and consequently a low genetic distance between the various AEZs considered. Accessions from Sudan Savanna showed the highest percentage genetic similarity with those collected from North Guinea Savanna (99.51\%) and Southern Guinea Savanna. Nei's coefficient showed the highest genetic distance accessions of Sudan Savanna and Derived Savanna with genetic distance of $14.54 \%$ (Table 4).

Cluster analysis of the dendrogram (Figure 3) constructed from Jaccard's similarity coefficient showed six groups; four contained one accession each, one group contained two accessions (P3 and P4), and the last group contained the remaining seventeen (17) accessions at Jaccard's coefficient of 0.70 . The accessions P31 and P32 showed the highest similarity followed by P5 and P13 with Jaccard's similarity coefficient of 0.99 and 0.95 , respectively. 
TABLE 3: Genetic diversity analysis within each agroecological zone.

\begin{tabular}{|c|c|c|c|c|c|}
\hline AEZ & ONA & ENA & GD & NPL & PP (\%) \\
\hline 1 & $1.32 \pm 0.47$ & $1.17 \pm 0.28$ & $0.11 \pm 0.16$ & 26 & 32.10 \\
\hline 2 & $1.14 \pm 0.34$ & $1.10 \pm 0.24$ & $0.06 \pm 0.14$ & 11 & 13.58 \\
\hline 3 & $1.11 \pm 0.32$ & $1.09 \pm 0.26$ & $0.05 \pm 0.14$ & 9 & 11.11 \\
\hline 4 & $1.14 \pm 0.34$ & $1.08 \pm 0.23$ & $0.05 \pm 0.13$ & 11 & 13.58 \\
\hline 5 & $1.30 \pm 0.46$ & $1.21 \pm 0.32$ & $0.12 \pm 0.19$ & 24 & 29.63 \\
\hline 6 & $1.65 \pm 0.48$ & $1.21 \pm 0.24$ & $0.15 \pm 0.14$ & 53 & 65.43 \\
\hline 7 & $1.65 \pm 0.48$ & $1.25 \pm 0.24$ & $0.18 \pm 0.14$ & 53 & 65.43 \\
\hline
\end{tabular}

Values are represented in mean \pm SD; AEZ: Agroecological zones; ONA: observed number of alleles; ENA: effective number of alleles; GD: gene diversity; NPL: number of polymorphic loci; PP: percentage polymorphism; 1: Sahel Savanna; 2: Sudan Savanna; 3: North Guinea Savanna; 4: Midaltitude; 5: South Guinea Savanna; 6: Derived Savanna; 7: Humid forest.

TABLE 4: Genetic correlation between agroecological zones.

\begin{tabular}{lccccccc}
\hline AEZ & 1 & 2 & 3 & 4 & 5 & 6 & 7 \\
\hline 1 & & 0.99 & 0.99 & 0.98 & 0.89 & 0.97 & 0.96 \\
2 & 0.01 & & 0.99 & 0.99 & 0.86 & 0.98 & 0.99 \\
3 & 0.02 & 0.01 & & 0.98 & 0.88 & 0.98 & 0.98 \\
4 & 0.02 & 0.01 & 0.20 & & 0.87 & 0.97 & 0.97 \\
5 & 0.12 & 0.14 & 0.12 & 0.14 & & 0.91 & 0.88 \\
6 & 0.04 & 0.02 & 0.02 & 0.02 & 0.09 & & 0.98 \\
7 & 0.04 & 0.01 & 0.03 & 0.03 & 0.12 & 0.02 & \\
\hline
\end{tabular}

Nei's genetic similarity index (above diagonal) and genetic distance index (below diagonal); AEZ: agroecological zones; 1: Sahel Savanna; 2: Sudan Savanna; 3: North Guinea Savanna; 4: Midaltitude; 5: South Guinea Savanna; 6: Derived Savanna; 7: Humid forest.

\section{Discussion}

The results obtained from RAPD analysis of P. biglobosa indicate intra- and interpopulation variations from the accessions evaluations were low. Similar results were reported in the inter- and intrapopulation variation study of $P$. biglobosa genetic diversity using isoenzymatic electrophoresis by Sina [13]. The ten RAPD primers used generated 81 bands and a polymorphic range of $11.11-65.43 \%$ similar to that of Thangjam et al. [20] which reported 95 scorable bands from twelve primers and a polymorphic range of $0-57.14 \%$ in a study of genetic diversity of a close relative, $P$. timoriana. The result shows that high polymorphism exists in the accessions of P. biglobosa studied. Monteleone et al. [21] also reported 64 polymorphic bands from ten RAPD markers in their study and were able to detect genetic diversity differences in fifteen populations of subspecies of Pinus mugo from their evaluation.

Ouedraogo [11] reported a large variation in P. biglobosa between the West African provenances in terms of adaptability and morphology attributed to several factors, among which are genetics and environment. Adesoye et al. [14] also reported a wide genetic variance among the accessions of $P$. biglobosa evaluated using seedling morphological traits which may be attributed to the different environmental influence from the various AEZs; Nei's genetic diversity analysis from this present study indicated an overall low genetic diversity within the AEZs, with the Humid forest zone having the highest gene diversity of $0.18 \pm 0.14$. This result corroborates Hamrick and Godt [22] that species with small geographic ranges tend to maintain less genetic diversity than geographically widespread species. The highest percentage polymorphism observed in both the derived Savanna and Humid forest may be attributed to the fact that they constitute the largest AEZs in Nigeria as well as the zone with the highest number of accessions studied. Likewise among the AEZs studied, the genetic diversity was generally low, thus indicating a narrow genetic base among the accessions of the different zones. This has implications in considerations for the conservation. In this regard, Schaal et al. [23] stated that genetic diversity is a prerequisite for future adaptive change and evolution and has a profound effect for species conservation. The genetic distance was least between the Sudan Savanna and Northern Guinea Savanna. These zones are close in terms of location and P. biglobosa being an open pollinating plant allows for gene flow between populations corroborating the work of Sayed et al. [24] that there is possibly free or random pollen flow and fertilization in close natural populations hence narrowing the genetic distance between them.

The present study shows a low genetic distance ( 0.01 to 0.20 ) from the RAPD marker analysis indicating a common ancestry. Sina [13] reported a similar result (genetic distance range 0 to 0.24 ) by means of isoenzymatic analysis and indicated that the presence of a low genetic distance shows that the populations were similar enough to belong to the same genetic group. The genetic diversity and genetic structure of $P$. biglobosa result from its evolutionary history without bottleneck sequence, the reproductive biology with high flowering synchronism and outcrossing rates, and the P. biglobosa parkland systems that human developed through years and as such have facilitated gene flow between populations [13].

The distribution of genotypes among clusters did not correspond accurately with their geographical pattern. Cluster analysis shows that the subclusters were more or less heterogeneous and contained accessions from different AEZs with a relatively high Jaccard's similarity coefficient of 0.70 . Similar result was reported by Adesoye et al. [14] from their evaluation of morphological differences in seedling traits of Parkia accessions collected from different Nigerian AEZs. They suggested that the situation was possible because 


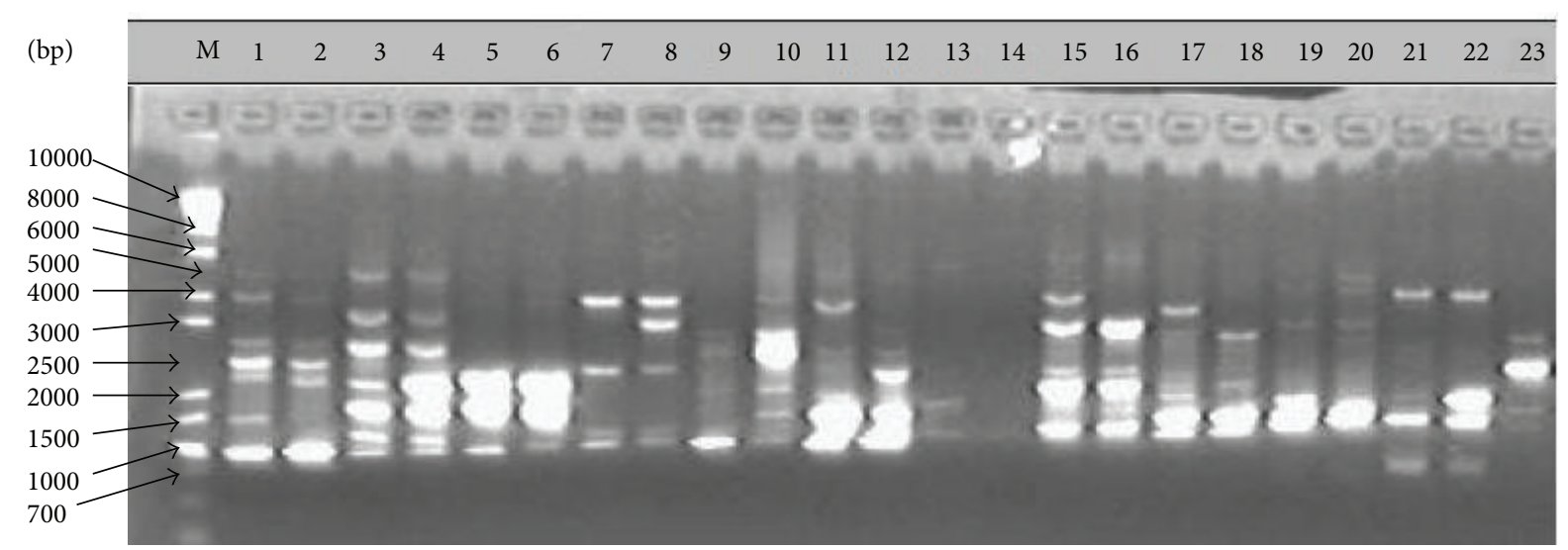

Figure 2: Amplified RAPD polymorphic bands of OPF-10 across the 23 accessions of P. biglobosa.



FIGURE 3: Dendrogram results from RAPD analysis showing the relationship between the 23 accessions of P. biglobosa. P1-Oyo (Derived), P2Ondo (Humid), P3-Abuja (Derived), P4-Ogun (Derived), P5-Benue (Derived), P6-Niger (S. Guinea), P7-Ondo (Humid), P8-Ondo (Humid), P9-Delta (Derived), P10-Plateau (Midaltitude), P11-Benue (Derived), P12-Oyo (Derived), P13-Katsina (Sudan), P14-Gombe (N. Guinea), P15Kano (Sudan), P16-Yobe (Sahel), P22-Bauchi (N. Guinea), P23-Kaduna (N. Guinea), P24-Kaduna (N. Guinea), P28-Yobe (N. Guinea), P31Plateau (Midaltitude), P32-Plateau (Midaltitude), and P36-Ogun (Humid). 
of different genetic makeup of genotypes and subsequent natural selection during their development. The crossing between genotypes belonging to same clusters is not likely to give heterotic desirable segregants as suggested by Adesoye et al. [14]. Additionally, the frequency of seed exchange over wide geographic-ethnic regions is thought to also be responsible for this outcome, as Ntudu [25] from survey of seed markets assessment reported that seeds are generally exchanged between small farmers and marketers in Africa.

In conclusion, while the occurrence of a narrow genetic base observed between the accessions of P. biglobosa may mean that they resulted from a common gene pool, it is also possible that this high genetic similarity may also result from its outcrossing nature over a long time resulting in high homozygosity. This makes it important for further research efforts using more specific molecular markers to ensure a better understanding of the diversity in P. biglobosa so as to enhance the selection of germplasm in conservation of the species as well as fostering a better understanding of the diversity within the species.

\section{Conflict of Interests}

The authors declare that there is no conflict of interests regarding the publication of this paper.

\section{References}

[1] G. Campbell-Platt, "African locust bean and it's West African fermented products-Dadawa," Ecology of Food and Nutrition, vol. 9, pp. 123-132, 1980.

[2] B. Hopkins, "The taxonomy, reproductive biology and economic potentials of Parkia in Africa and Madagascar," Botany Journal of Linnean Society, vol. 87, pp. 135-167, 1983.

[3] A. E. Gbadamosi, "Genetic variation in Enantia chlorantha (oliv). A medicinal plant," Journal of Food, Agriculture and Environment, vol. 3, no. 1, pp. 153-156, 2005.

[4] C. E. Udobi, J. A. Onaolapo, and A. Agunu, "Antibacterial potentials of the methanolic extract and aqueous fraction of the stem bark of the African locust bean (Parkia biglobosa)," European Journal of Scientific Research, vol. 43, no. 4, pp. 590602, 2010

[5] D. A. Alabi, O. R. Akinsulire, and M. A. Sanyaolu, "Nutritive and industrial utility values of African locust bean seeds Parkia biglobosa (Jacq.) Benth," Proceedings of Science Association of Nigeria, vol. 25, pp. 105-110, 2004.

[6] C. Orwa, A. Mutua, R. Kindt, R. Jamnadass, and A. Simons, "Agroforestree Database: a tree reference and selection guide version 4.0," http://www.worldagroforestry.org/sites/treedbs/ treedatabases.asp.

[7] E. H. C. Kwon-Ndung, C. D. Chup, N. A. Binbol, and A. Ismaila, "Ecological implications of climate change on the genetic diversity and distribution of African locust bean parkia biglobossa in Central Nigeria," IOP Conference Series: Earth and Environmental Science, vol. 6, no. 37, Article ID 372026, 2009.

[8] F. R. Irvine, Woody Plants of Ghana with Special References to Their Trees, Oxford University Press, London, UK, 1961.

[9] T. H. Hagos, "A revision of genius Parkia (Mim) in Africa," Acta Botanica Nearthandica, vol. 11, pp. 231-265, 1962.
[10] I. C. Obizobia, Fermentation of African Locust Bean. Text on Nutritional Quality of Plant Fruits, Edited by A. U. Osagie and O. U. Eka, Post-Harvest Research Unit, Department of Biochemistry, University of Benin, Benin City, Nigeria, 2000.

[11] A. S. Ouedraogo, Parkia biglobosa (Leguminosae) en Afrique de l'Ouest: biosystematique et amelioration [Ph.D. thesis], Institute of Forestry and Natural Resources, Wageningen, The Netherlands, 1995.

[12] Z. Teklehaimanot, J. Lanek, and H. F. Tomlinson, "Provenance variation in morphology and leaflet anatomy of Parkia biglobosa and its relation to drought tolerance," Trees, vol. 13, no. 2, pp. 96102, 1998.

[13] S. Sina, Reproduction et diversité génétique chez Parkia biglobosa (Jacq.) [G. Don. doctoral thesis], Wageningen University and Research Centre, Wageningen, The Neitherlands, 2006.

[14] A. I. Adesoye, C. O. Ogunremi, and O. O. Aina, "Genetic variation and heritability of seedling traits in African locust BeanParkia biglobosa (Jacq.) R.Br. Ex G.Don," Legume Research, vol. 36, no. 2, pp. 89-97, 2013.

[15] J. Welsh and M. McClelland, "Fingerprinting genomes using PCR with arbitrary primers," Nucleic Acids Research, vol. 18, no. 24, pp. 7213-7218, 1990.

[16] J. Kapteyn and J. E. Simon, "The use of RAPDs for assessment of identity, diversity, and quality of Echinacea," in Trends in New Crops and New Uses, A. Janick and A. Whipkey, Eds., pp. 509513, ASHS Press, Alexandria, Va, USA, 2002.

[17] K. Subramanyam, D. Muralidhararao, and N. Devanna, "Genetic diversity assessment of wild and cultivated varieties of Jatropha curcas (L.) in India by RAPD analysis," African Journal of Biotechnology, vol. 8, no. 9, pp. 1900-1910, 2009.

[18] S. L. Dellaporta, J. Wood, and J. B. Hicks, "A plant DNA minipreparation: version II," Plant Molecular Biology Reporter, vol. 1, no. 4, pp. 19-21, 1983.

[19] M. Nei and W. H. Li, "Mathematical model for studying genetic variation in terms of restriction endonucleases," Proceedings of the National Academy of Sciences of the United States of America, vol. 76, no. 10, pp. 5269-5273, 1979.

[20] R. Thangjam, D. Maibam, and J. G. Sharma, "Detection of genetic diversity in Parkia timoriana (DC.) Merr. using randomly amplified polymorphic DNA analysis," Journal of Food Agricultural Environment, vol. 1, no. 3-4, pp. 46-49, 2003.

[21] I. Monteleone, D. Ferrazzini, and P. Belletti, "Effectiveness of neutral RAPD markers to detect genetic divergence between the subspecies uncinata and mugo of Pinus mugo Turra," Silva Fennica, vol. 40, no. 3, pp. 391-406, 2006.

[22] J. L. Hamrick and M. J. W. Godt, "Allozyme diversity in plants," in Plant Population Genetics, Breeding and Genetic Resources, D. A. H. Brown, M. T. Clegg, A. L. Kahler, and B. S. Weir, Eds., pp. 43-63, Sinauer, Sunderland, Mass, USA, 1989.

[23] B. A. Schaal, D. A. Hayworth, K. M. Olsen, J. T. Rauscher, and W. A. Smith, "Phylogeographic studies in plants: problems and prospects," Molecular Ecology, vol. 7, no. 4, pp. 465-474, 1998.

[24] M. Z. H. Sayed, S. B. S. SMohammed, and M. S. Ramisah, "Analysis of random amplified polymorphic DNA (RAPD) of Artemisia capillaries (Worm wood capillary) in east coast of Penisular Malaysia," World Applied Science Journal, vol. 6, no. 7, pp. 976-986, 2009.

[25] W. H. Ntudu, Genetic diversity of Bambara groundnut (Vigna subterraneea (L) Verdc) in Tanzania [Ph.D. thesis], The Royal Veteriary and Agricultural University, Copenhagen, Denmark, 2002 . 

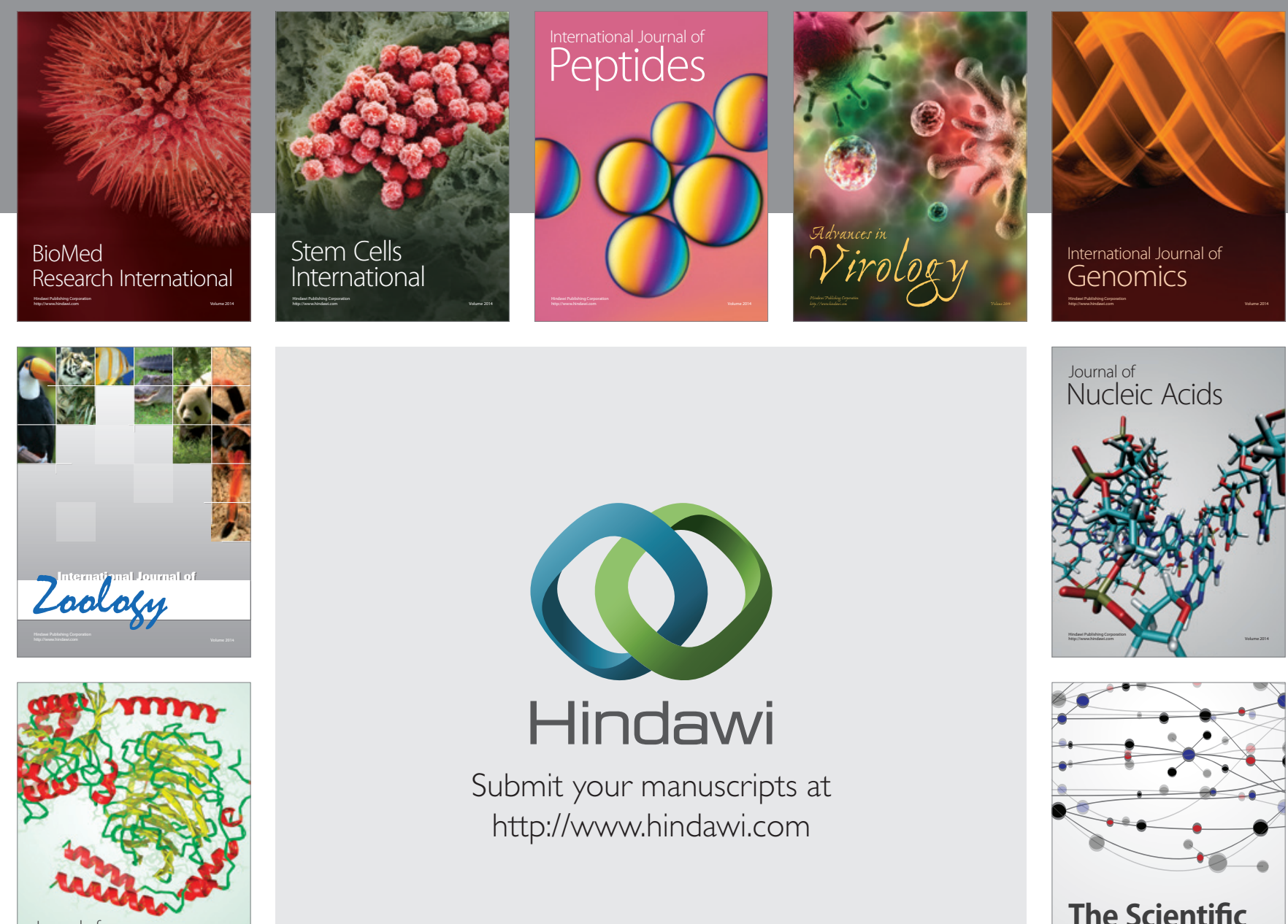

Submit your manuscripts at

http://www.hindawi.com

Journal of
Signal Transduction
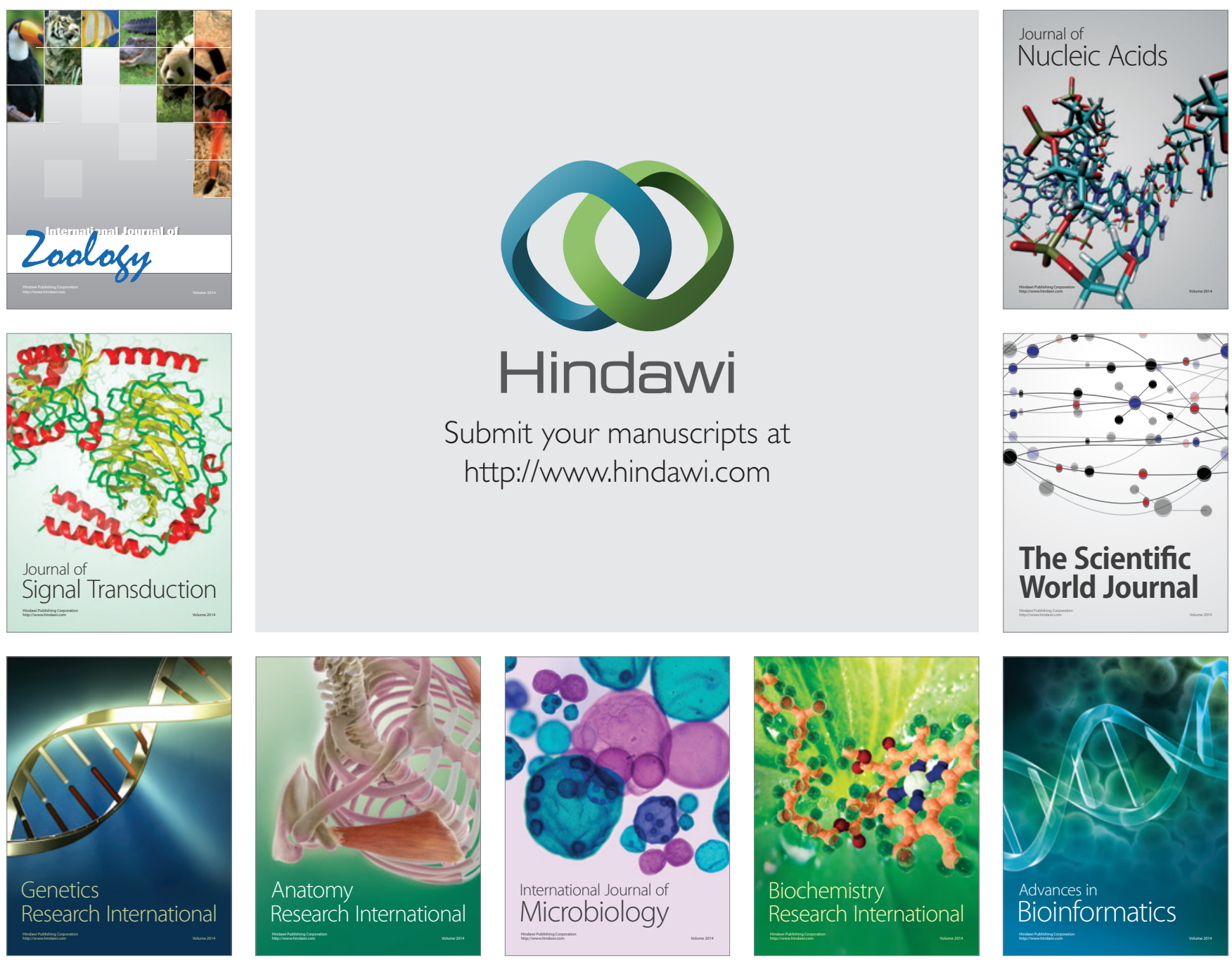

The Scientific World Journal
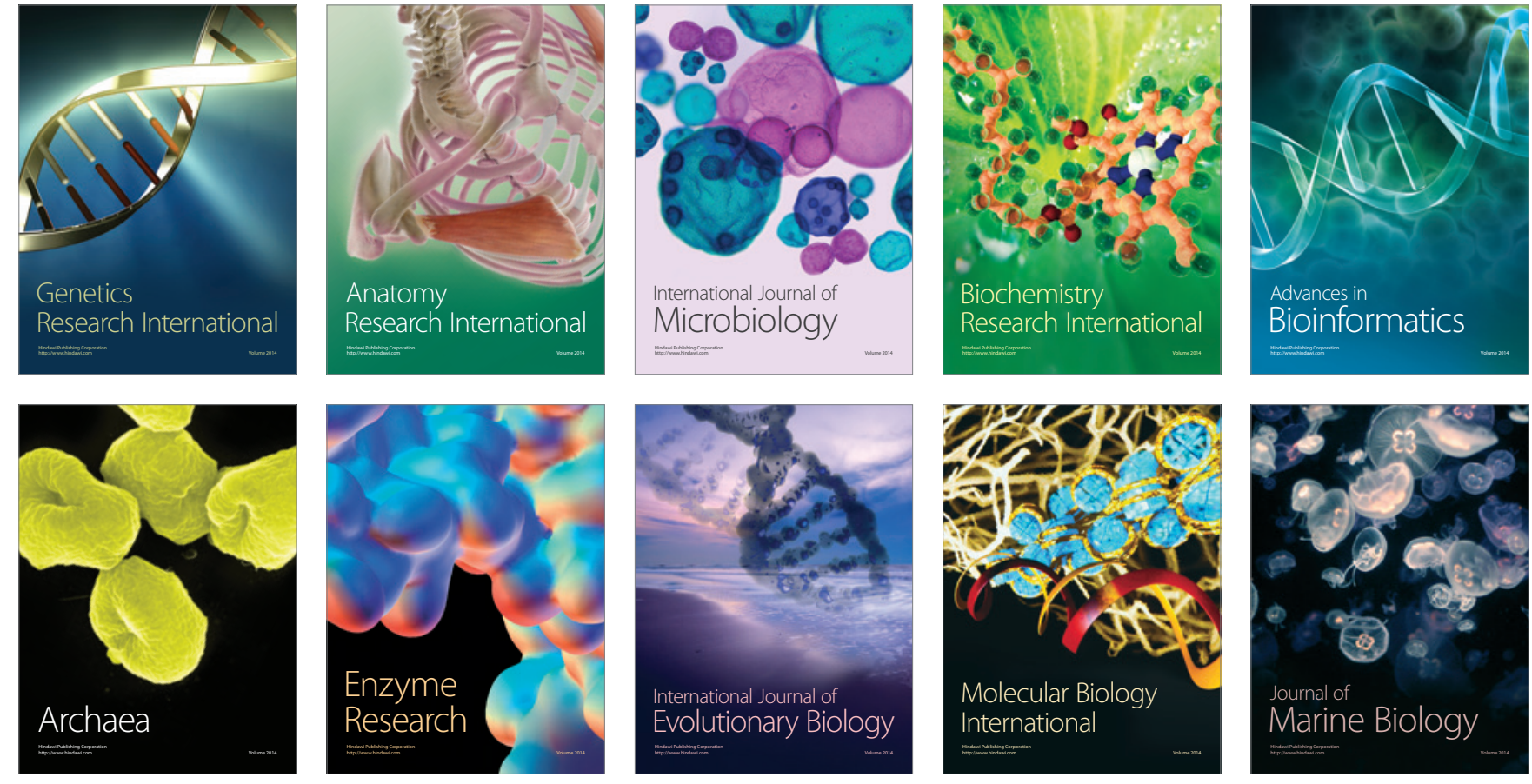